\title{
PENGARUH LAMA PENYIMPANAN SETELAH DIPERAH TERHADAP pH, BERAT JENIS DAN JUMLAH KOLONI BAKTERI SUSU KERBAU
}

\author{
Elly Roza dan Salam Aritonang \\ Fakultas Peternakan Universitas Andalas, Padang
}

\begin{abstract}
The aim of the present research was to study the quality changes of buffalo's milk stored in different time period after milking. About 10 liters of fresh buffalo milk which were obtained from Lembah Gumanti, Solok district were used in the experiment. The milk was divided and placed into four groups and stored in room temperature for 4 different time periods: 2, 4, 6 and 8 hours immediately after milking. Parameter measured included: $\mathrm{pH}$, specific gravity and colony number of bacteria. Data was statistically analyzed by variance analysis in Block Randomized Design (RBD) with 4 treatments and 5 replicates. The results indicated that there was significant effect $(\mathrm{P}<0.01)$ among the treatment on the characteristic of buffalo milk. It showed that increasing of the storage time after milking have decreased $\mathrm{pH}$ and increased specific gravity and bacteria count.
\end{abstract}

Key words: buffalo's milk, $p H$, specific gravity, bacteria

\section{Pendahuluan}

Bahan pangan berkualitas tinggi yang dibutuhkan oleh manusia umumnya merupakan produk yang mudah sekali rusak. Salah satu diantaranya adalah susu. Susu memiliki sifat yang mudah rusak karena kandungan gizinya merupakan media yang baik untuk pertumbuhan mikroorganisme. Mikroorganisme ini dapat merubah kualitas dan sifat susu yang meliputi $\mathrm{pH}$, berat jenis dan jumlah koloni bakteri susu dalam waktu yang singkat.

Salah satu yang dapat menghasilkan susu dengan nilai gizi yang lebih baik daripada susu sapi adalah kerbau. Susu kerbau umumnya tidak dikonsumsi dalam keadaan segar seperti halnya susu sapi. Padahal susu kerbau lebih kaya dari susu sapi dalam hal zat makanan utama dan jumlah padatan (Syamsuddin, 1979). Di Sumatera Barat susu kerbau tidak asing lagi karena susu kerbau merupakan bahan utama dalam pembuatan dadih. Dadih merupakan makanan tradisional bagi masyarakat Sumatera Barat.

Dalam penanganan susu kerbau biasanya petani peternak tidak langsung melakukan pendinginan atau pemanasan terlebih dahulu. Susu segar setelah diperah disimpan pada suhu ruang untuk beberapa jam kemudian menunggu pengolahan lebih lanjut. Suhu mempengaruhi lama penyimpanan susu setelah diperah yang juga akan diikuti oleh perubahan kualitas susu sehingga susu menjadi rusak dan tidak dapat dikonsumsi lagi.

Berdasarkan uraian diatas maka dilakukan penelitian yang bertujuan untuk mempelajari perubahan kualitas susu kerbau yang disimpan dalam jangka waktu berbeda setelah diperah. Parameter yang diamati 
antara lain: $\mathrm{pH}$, berat jenis dan jumlah koloni bakteri susu kerbau.

Manfaat penelitian ini adalah untuk memberikan informasi kepada masyarakat tentang daya tahan dan kualitas susu segar yang disimpan dalam suhu ruang, serta menambah wawasan pemikir bagi peneliti dan manfaat bagi ilmu pengetahuan.

\section{MATERI DAN METODE}

Materi penelitian ini menggunakan 10 liter susu kerbau segar hasil pemerahan pagi hari yang berasal dari Lembah Gumanti, Solok. Alat-alat dan bahan-bahan yang digunakan adalah plastik polietilen, timbangan dan peralatan untuk analisis laboratorium lainnya.

Metode yang digunakan adalah metode eksperimen dengan mengunakan Rancangan Acak Kelompok (RAK) yang terdiri dari 4 perlakuan dan 5 ulangan dan kelompok berlaku sebagai ulangan. Sebagai perlakuan adalah lama penyimpanan susu setelah diperah yaitu 2 jam (A), 4 jam (B), 6 jam (C) dan 8 jam (D). Peubah yang diamati $\mathrm{pH}$, berat jenis dan jumlah koloni bakteri susu kerbau.
Data yang diperoleh dianalisis dengan uji $F$ dan analisis regresi korelasi sederhana dan diuji lanjut dengan DMRT (Duncan Multiple Range Test).

\section{Hasil dan Pembahasan}

Pengaruh perlakuan terhadap $\mathrm{pH}$, berat jenis dan jumlah koloni bakteri susu kerbau dapat dilihat pada Tabel 1.

\section{Pengaruh Perlakuan Terhadap $\mathrm{pH}$}

Dari Tabel 1 dapat dilihat rataan $\mathrm{pH}$ susu kerbau yang tertinggi yaitu 6.282 dan terendah 5,338. Hasil analisis keragaman menunjukkan bahwa perlakuan memberikan pengaruh berbeda sangat nyata $(\mathrm{P}<0.01)$ terhadap $\mathrm{pH}$. Hal ini sesuai dengan pendapat Sugitha dan Djalil (1989) bahwa penurunan $\mathrm{pH}$ disebabkan oleh aktivititas mikroorganisme di dalam susu selama penyimpanan yang dapat menyebabkan terjadinya fermentasi laktosa menjadi asam laktat. Disamping itu penanganan yang tidak baik dan suhu penyimpanan juga mempengaruhi.

Tabel 1. Rataan pH, Berat Jenis dan Jumlah Koloni Bakteri pada Susu Kerbau yang Disimpan dalam Jangka Waktu Berbeda

\begin{tabular}{|c|c|c|c|}
\hline Perlakuan & PH & Berat jenis & $\begin{array}{c}\text { Koloni bakteri } \\
\left(\times 10^{4} \text { CFU/ml susu }\right)\end{array}$ \\
\hline A & $6,282^{\mathrm{A}}$ & $1,0293^{\mathrm{A}}$ & $79,6^{\mathrm{A}}$ \\
\hline $\mathrm{B}$ & $5,800^{\mathrm{B}}$ & $1,0305^{\mathrm{AB}}$ & $98,4^{\mathrm{B}}$ \\
\hline $\mathrm{C}$ & $5,608^{\mathrm{C}}$ & $1,0317^{\mathrm{B}}$ & $135,0^{\mathrm{C}}$ \\
\hline $\mathrm{D}$ & $5,338^{\mathrm{D}}$ & $1,0349^{\mathrm{C}}$ & $278,98^{\mathrm{D}}$ \\
\hline
\end{tabular}

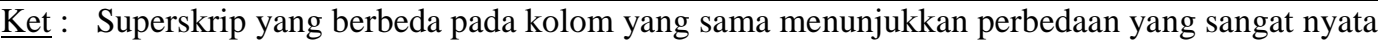
$(\mathrm{P}<0,01)$ 


\section{Pengaruh Perlakuan Terhadap Berat Jenis}

Dari Tabel 1 dapat dilihat rataan berat jenis susu kerbau yang tertinggi yaitu 1,0349 dan terendah 1,0293. Hasil analisis keragaman menunjukkan, bahwa perlakuan memberikan pengaruh berbeda sangat nyata $(\mathrm{P}<0,01)$ terhadap berat jenis susu kerbau. Hasil uji jarak berganda Duncan menunjukkan, bahwa berat jenis susu meningkat. Hal ini menunjukkan bahwa pengaruh penyimpanan pada susu menyebabkan terjadinya peningkatan berat jenis yang disebabkan karena memadatnya lemak. Hal ini sesuai dengan pernyataan Hadiwiyoto (1982), bahwa berat jenis susu berubah-ubah menurut lamanya susu dibiarkan pada suhu ruang, dimana berat jenis yang dekat dengan waktu saat pemerahan lebih kecil dari berat jenis yang jauh dari saat pemerahan antara lain disebabkan oleh memadatnya lemak. Sedangkan lemak yang padat mempunyai berat jenis yang lebih besar dari lemak cair, disamping adanya penguapan gas-gas dalam susu.

\section{Pengaruh Perlakuan terhadap Jumlah Koloni Bakteri}

Dari Tabel 1 dapat dilihat rataan jumlah koloni bakteri susu kerbau yang tertinggi yaitu $278,9 \times 10^{4}$ dan terendah 79,6 $\times 10^{4}$. Hasil analisis keragaman menunjukkan bahwa perlakuan memberikan penga-ruh yang berbeda sangat nyata $(\mathrm{P}<0,01)$ terhadap jumlah koloni bakteri susu. Hasil uji jarak Duncan menunjukkan bahwa diantara masing-masing perlakuan satu sama lain saling berbeda nyata. Keadaan ini menunjukkan bahwa semakin lama penyimpanan susu setelah pemerahan pada suhu ruang maka jumlah koloni bakteri pun meningkat. Hal ini sesuai dengan pernyataan Eckles et al. (1980), bahwa bakteri pada suhu ruang akan berkembang/ membelah diri pada tiap setengah jam. Pembelahan ini berlangsung secara geometrik (deret ukur).

Perbedaan yang sangat nyata antara perlakuan juga disebabkan karena selama penyimpanan susu akan diikuti juga oleh menurunnya $\mathrm{pH}$ susu. $\mathrm{PH}$ yang rendah akan menyebabkan pertumbuhan mikroorganisme yang meningkat karena suasana asam merupakan kondisi yang baik untuk pertumbuhan mikroorganisme. Menurut Soeparno (1996) salah satu faktor utama yang mempengaruhi mikroorganisme adalah $\mathrm{pH}$.

Hasil analisis regresi menunjukkan hubungan yang erat antara $\mathrm{pH}$ susu dengan jumlah koloni bakteri dengan angka korelasi r sebesar 0,844 dengan $Y=1249,8-191,38 X$. Untuk lebih jelasnya lagi hubungan antara $\mathrm{pH}$ dengan jumlah koloni bakteri pada susu dapat dilihat pada Gambar 1.

Gambar 1 menunjukkan, bahwa pada $\mathrm{pH}$ yang rendah jumlah koloni bakteri akan meningkat dan sebaliknya. Hal ini disebabkan karena pada $\mathrm{pH}$ yang rendah aktivitas bakteri pembentuk asam berkembang dengan cepat. 


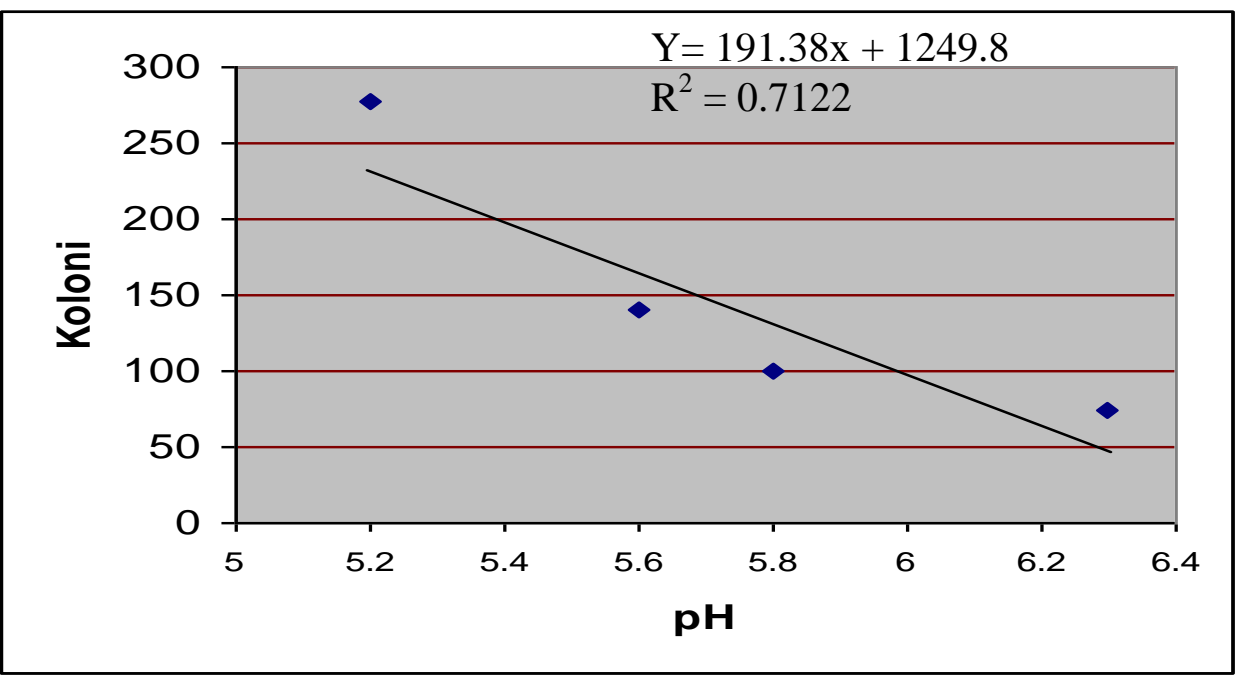

Gambar 1. Hubungan pH dengan Jumlah Koloni Bakteri Susu Kerbau

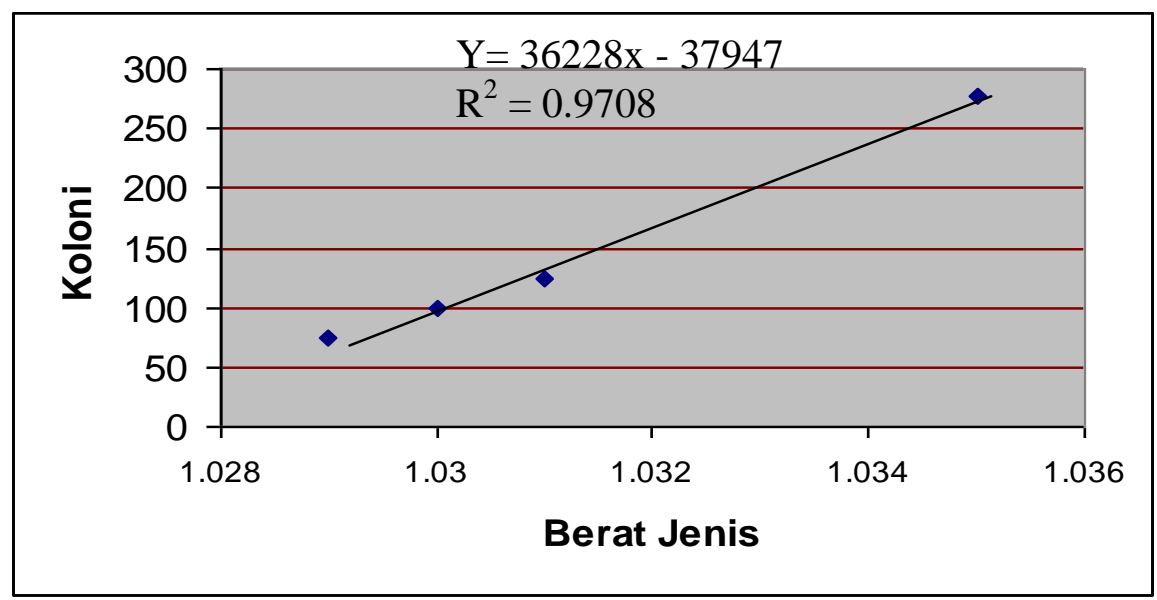

Gambar 2. Hubungan Berat Jenis dengan Jumlah Koloni Bakteri Susu

Disamping $\mathrm{pH}$, berat jenis susu pun berpengaruh terhadap perkembangan jumlah koloni bakteri, berat jenis yang tinggi akan diikuti oleh jumlah koloni bakteri yang tinggi pula. Hal ini disebabkan karena memadatnya lemak dan meningkatnya keasaman susu sehingga mengakibatkan terjadinya pengumpalan-pengumpalan pada susu yang menyebabkan peningkatan berat jenis.

Hasil analisis regresi menunjukkan hubungan yang erat antara berat jenis dengan jumlah koloni bakteri dengan angka korelasi $r$ sebesar 0,985 dengan $\mathrm{Y}=-37947+$ 36928X. Untuk lebih jelasnya lagi hubungan antara berat jenis dengan jumlah koloni bakteri pada susu dapat dilihat pada Gambar 2.

Gambar 2 menunjukkan bahwa pada berat jenis susu yang rendah maka jumlah koloni bakteri susu pun rendah dan sebaliknya. Berat jenis susu yang dekat dengan waktu saat pemerahan lebih kecil dan jumlah bakteri pun lebih rendah dibanding berat jenis susu yang disimpan lebih lama setelah pemerahan. Hal ini disebabkan lama penyimpanan susu 
pada suhu ruang dapat meningkatkan keasaman dan memadatnya lemak, sehingga berat jenis susu meningkat dan jumlah bakteri pun lebih tinggi.

\section{Kesimpulan}

Dari hasil penelitian yang telah dilakukan dapat diambil kesimpulan sebagai berikut :

1. Semakin lama penyimpanan susu setelah diperah pada suhu ruang akan menurunkan $\mathrm{pH}$ susu, menaikkan berat jenis dan diikuti pula dengan peningkatan jumlah koloni bakteri susu kerbau.

2. Terdapat hubungan yang erat antara $\mathrm{pH}$ dan berat jenis susu dengan jumlah koloni bakteri susu kerbau.

\section{Daftar Pustaka}

Buckle, K.A, R.A. Edwards, G.H. Fleet dan M. Wootton. 1987. Ilmu Pangan Cetakan ke-2. Terjemahan Hari Purnomo dan Andiono. Penerbit Universitas Indonesia, Jakarta.
Dwijoseputro, D. 1982. Dasar-dasar Mikrobiologi. Cetakan ke-6, Penerbit Djembatan, Jakarta.

Eckles, C.H, W.R. Comb and H. Macy, 1980. Milk and Milk Product, 4 th Ed, MC. Grow Hill Books Company Inc. New York.

Hadiwiyoto, S. 1982. Teknik Uji Mutu Susu dan Hasil Olahannya, Liberti, Yogyakarta.

Judkins dan Keener, 1996. Milk Production and Processing, $4^{\text {th }}$ Ed, John Wiley and Soms Inc. New York.

Soeparno, 1996. Pengolahan Hasil Ternak. Cetakan ke-1, Universitas Terbuka, Jakarta.

Sugitha, I.M dan M. Djalil, 1989. Susu, Penanganannya dan Teknologinya, Fakultas Peternakan Universitas Andalas, Padang.

Syamsuddin, C. 1979. Case Study Kerbau Perah di Sumatera Barat, Universitas Andalas, Padang.

\section{Alamat korespondensi: Elly Roza \\ Jurusan Produksi Ternak, Fakultas Peternakan \\ Universitas Andalas, Kampus Limau Manis, Padang \\ Telp/Fax.: 0751-71464,}

Diterima: 12 Januari 2005, Disetujui: 4 Januari 2006 